\title{
Study on Continuing Education under the Network Environment
}

\author{
Lehui Huang $^{1,}$, Miaomiao $\mathrm{Li}^{2, \mathrm{~b}}$ \\ ${ }^{1}$ Education School, Jiangxi Science \& Technology Normal University, Nanchang 330038, China \\ ${ }^{2}$ Education School, Jiangxi Science \& Technology Normal University, Nanchang 330038, China \\ aHLH8899@163.com; 'biMiaomiao0710@163.com
}

Keywords: network; network technology; continuing education

\begin{abstract}
The emergence of the internet has brought new changes to the human educational activities, especially the continuing education. The paper analyzes the development opportunities and challenge brought by the network to continuing education, and proposes the strategies of improving continuing education under the network environment.
\end{abstract}

\section{Introduction}

Today's world has entered into the information age, the science and technology has developed rapidly, and the knowledge economy has fully revealed. The network and modern distant education has become important means of modern education with the development of modern information technology. A hitherto unknown revolution caused by the information technology and the internet, makes the update cycle of knowledge become shorter and shorter, so people can keep up with the pace of the times only through continuous learning and updating knowledge constantly. In the new historical period, the network will give full play to its unique advantages and become an important form of continuing education.

\section{Opportunities bought by the network to continuing education}

It provides rich teaching resources for continuing education. In the implementation of network teaching, its information resource is three-dimensional from the point of space, but cross from the point of content. The resources are not only from the contents or teaching courseware provided by the local computer, the more is from online information sources distributing in the world. The teachers and students can obtain the newest first hand data, listen to the lecture of the world first-class teachers, and consult the best expert through the office, library, school or home into the network. Teachers can add and modify teaching content on the internet whenever and wherever, open the new courses or lectures, so as to make the students gain the latest and the most urgent knowledge, especially are suitable to the need of continuing education.

It provides a variety of teaching expression modes for continuing education. In the process of network teaching, integrate a variety of text, graphics, images, audio and video; provide text and hypertext, concrete and abstract knowledge and information. Therefore, students can link to each big database and other related sites in the world to consult the relevant materials, to not only obtain a lot of information, but also realize that learning to the teachers and textbooks is a kind of learning resources through independent searching the material on the internet, so as to find vast resources and give full play to the function of self education. Through simulation and virtual technology, express the fact and experience that can't be expressed with practical conditions reveal and transfer through the multimedia, to enrich students' horizons and increasing the amount of information of students' learning in continuing education.

It provides advanced teaching means for continuing education. Network teaching makes full use of network technology, multimedia technology, computer technology and other modern information technology. While absorbing the advantages of traditional teaching methods, network teaching makes up for their deficiencies, integrates the characteristics of modern media, and makes full use of various media means effectively to optimize the teaching methods. The school can also hire the 
best teachers through network teaching, or allow several teachers to teach a course to improve the teaching effect, so as to let every teacher teach the best part, thereby optimizing the teaching resources and achieving good results in continuing education.

It provides personalized teaching environment for continuing education. The diversification of network environment provides broad space for the development of personalized teaching. Both teaching can teach or learn according to own needs, so as to make personalized education possible. Network teaching has no limitation of time and geographic, so learners can choose learning content, make learning plans, determine learning progress, and choose learning method according to their own interests, knowledge structure, work requirements and time, which creates conditions for those limited by working time, residence place, age, and family persons.

It provides repeatable learning process for continuing education. Because the online teaching information exists in the forms of text and hypertext, reproduction of information is simple, rapid and economical, and a CD-ROM can store a lot of learning contents. Online teaching can save students' time on books and classes, and electronic lesson plans and teaching courseware can be used multiple times or copied. The students can reproduce the teaching process according to their own learning. Learning through the network can simplify unnecessary learning process in continuing education, liberate them from the arduous task of learning, so as to reduce the burden of students and improve the learning efficiency.

\section{Challenge brought by the internet to continuing education}

It requires to reform traditional education ideas. For all the time, in the training goal, confine to the old idea "intellectualism", which can't cultivate the science and technology talents adapting to the development of the knowledge economical society; in the teaching contents, take the book knowledge as the center, which can't reflect the needs of the development of information society and the spirit of the network times; in the teaching method, focus on teachers and ignore the initiative and independence of students in the process of teaching; in the teaching form, emphasize the standardization of knowledge imparting and neglect students' personality; in the teaching methods, generally use the textbook, chalk, blackboard, chart and other static models, lagging behind the development of the times. The development of computer multimedia and network technology will completely lash the theory foundation of modern education, to prompt us to rethink the education theory forming under the industrial civilization, re-inspect the education idea and practice since the industrial revolution, rethink the concept and function of teachers, and re-position the relationship between teachers and students.

It requires to change traditional teaching model of continuing education. As with ordinary higher education, the continuing education implements the teacher-centered teaching mode all the time. In this mode, teachers are the active educator, students are passive recipients and indoctrination object, the media is the tool assisting teachers to instill in students, and the teaching material is the content. The teaching methods overemphasize the role of teachers while ignoring students' initiative and independence. For the students, it is a process of accepting knowledge passively. It can be imagined that, if the students, as the cognitive subject, are always in a passive position, it is difficult to reach the ideal teaching effect and cultivate creative talents, which is the biggest disadvantage of traditional teaching mode. With the emergence of network technology, the means of acquiring information is rich, and the teacher is no longer the only occupant, prophet and authority. The original teaching mode centering on teacher, classroom and teaching material will be broken completely, and replace by initiative teaching mode with re-experience, perception, inquiry and innovation.

It requires innovating traditional contents of continuing education. The traditional education, taking knowledge imparting and memory as the main content, pay special attention to the knowledge teaching and ignore the teaching of procedural and strategic knowledge, causing low hands-on ability and practical ability of students. Under the network technology background, knowledge of human science and technology further accelerate the growth rate. In contrast, the half-life of knowledge is shortening; the half-life of engineering knowledge reduces from five years 
to two years, the social science from ten years to five years, and the half-life of computer information is only half of a year. The rapid increasing of the overall knowledge and the rapid decline of knowledge half-life puts forward new requirements to update the education content. In order to go out of the traditional education mode taking declarative knowledge imparting as the center, continuing education based on the network should pay more attention to procedural knowledge, especially strategy knowledge in education. It should not only teach students the necessary knowledge, but also teach them the necessary skills and methods teaching them to learn knowledge and skills.

\section{Strategy of improving the continuing education under the network environment}

Standardize the management of continuing education and strengthen the consciousness of service by relying on the cyber source of the school campus. The students of continuing education have the characteristics of diversity and complexity, including all students in adult higher education, modern distance education, self-study examination and other various degrees or non degree education. Because students are large in number, and educational classes, learning level and mode are relatively more, in addition to most teaching school scattering around the school, students' living conditions and learning environment is relatively poor, which all bring more difficulty for the management of continuing education. Facing this kind of situation, rely on the cyber source of the school campus, start from the service to strengthen the education and management of all kinds of students. On one hand, according to the fact of all the students, increase the amount of information on the website and strengthen the function of service to provide quality service for teachers and students. For example, set up "enrollment and registration", "news" and other columns, so that teachers and students can know the events inside and outside school when entering the site; open the adult education, self-study, online education, vocational education, short-term training and other classified information, which is easy for students to understand the relevant policies and regulations of various continuing education; establish the teaching management, student employment, graduation and other topics, to meet the various needs of students. On the other hand, establish the online message column to answer or explore problems students do not understand or difficult to identify.

Become intimate friends of students and strengthen the ideological and political work of continuing education students by using the interactivity and equality of the network. Continuing education students are different in age. Some have rich social experience and strong thinking ability, self-control and self adjustment. Others are young, but their thinking is active, the ability of distinguishing right from wrong, self-control and self adjustment is relatively poor. There is a common point is: when encountering troubles or unpleasant, they may not talk with parents and school, but could be take heart words in line to seek help and comfort; when meeting the success or joy, they are more willing to share online with friends. Through online exchange, participant in students' discussion as equal friend identify, express their views to guide them to analyze and think, help them resolve doubts timely, carry out the ideal education and psychological consultation, make positive guidance and promote healthy spirit. At the same time, use a large number of positive typical examples and positive outlook on life and healthy sense of worth to carry out situation education for continuing education students, so as to let them know the country's political and economic situation, and use correct and positive spirit to capture the network position.

Do well in enrollment propaganda work by using the network platform. The network platform provides two-way communication channel for continuing education students and schools, and also plays an important role in the enrollment propaganda. At present, the candidates are increasing in the online population, so the school should timely adjust the way of enrollment propaganda, take further measures on the basis of conventional enrollment propaganda, and strengthen the online enrollment propaganda work. On one hand, increase the introduction of network enrollment types and the efforts of register advisory service. On the other hand, release the new enrollment dynamic timely and widely on the internet, announce the country's current enrollment policy, update the enrollment propaganda content, to let more students and parents understand various kinds of 
enrollment information comprehensively at the first time. At the same time, the school can truly introduce the achievement in cultivating continuing education students, and encourage students to choose combining their ambition.

\section{Conclusion}

The network has brought new challenges to the continuing education work, while brought hitherto unknown opportunities. Only adhering to the network for continuing education, service and management and for the students, practice boldly, advance with the times, and make full use of advantages of modern information technology, to promote the overall innovation of continuing education work by information construction, explore new ways and forms of continuing education service, and make continuing education achieve new progress.

\section{References}

[1]Jiayin Fang, Zhenfeng Jiang, Donghui He. On the development of continuing education[M]. Beijing: people’s liberation army press, 2003.

[2]Lijun Xue. Research on training mode of continuing education based on the network[J]. Jiangsu education, 2004(13).

[3]Ping Tan. On the impact of the network on the lifelong education[D]. Nanning: guangxi university, 2002.

[4]Songting Ma. Education evolution caused by the network technology[J]. Chinese adult education, 2004(5).

[5]Jianming Sun. On the education choice in informatization society[J]. Zhejiang social science, 2001(6). 